\section{Coordenadas de poder en Santiago de Chile, primera mitad del siglo XIX}

Power coordinates in Santiago, Chile, in the first half of the $19^{\text {th }}$ Century

\section{Marcelo Neira-Navarro ${ }^{* *}$}

\section{Resumen}

El trabajo estudia la relación entre el trazado urbano y fenómenos de poder en la ciudad de Santiago de la primera mitad del siglo XIX. Aspectos ideológicos y de práctica política, intentan controlar a los sujetos por medio de la vigilancia, subordinación y castigo. Hipotéticamente, la trama urbana, el "tablero de damero", permitió la existencia de los cuarteles,

\footnotetext{
El artículo es parte del proyecto DIULA No 46/2010, "Estado nacional en Chile. Primera mitad del siglo XIX". Una parte preliminar de este trabajo fue expuesto en el Simposio REPUBLICAS Y MONARQUIAS EN AMERICA LATINA: CHILE, MEXICO Y BRASIL, SIGLO XIX, en el Congreso Ciencias, tecnologías y culturas. Diálogo entre las disciplinas del conocimiento. Mirando al futuro de América Latina y el Caribe, realizado en la Universidad de Santiago de Chile entre el 29 de octubre y el 1 de noviembre de 2010 (www.internacionaldelconocimiento.org).

** Profesor jornada completa, Departamento de Ciencias Sociales, Universidad de Los Lagos. mneira@ulagos.cl
}

un plan abstracto que tuvo múltiples relaciones con el poder. Los cuarteles se objetivaron en un inventario de estrategias urbanas (cobro de impuestos, aseo urbano, control del funcionamiento institucional y organizaciones sociales) pero, sobre todo, soportaron las estrategias policiales, desde luego, vinculadas principalmente al control de la población.

Palabras clave: Historia de Santiago de Chile, coordenadas de poder, vida cotidiana

\begin{abstract}
In this research, the relationship between the checkerboard outline and power events in the city of Santiago in the first half of the 19th Century are studied. At that time, people were controlled through surveillance, subordination, and punishment because of ideological and political reasons. Hypothetically speaking, the city design known as "checkerboard" allowed the existence of police stations, being an abstract plan with many power relationships. Police stations materialized a number of urban strategies (tax collection, urban sanitation, control over institutions and social organizations), but their main objective was to support police strategies linked to maintaining population under control.
\end{abstract}

Key words: History of Santiago, power coordinates, daily life 


\section{Introducción}

La historia económica y urbana ha desarrollado un intenso trabajo sobre las ciudades en general y latinoamericanas en particular. Se ha investigado los efectos e impacto económico y su rol frente a ciertas actividades también económicas como el crédito o en cuanto al surgimiento y expansión del capitalismo a partir de la historia europea (Pirenne 1939; Le Goff 1992; Lezama 2008); también se ha estudiado el papel urbano en la expansión de las redes comerciales y en la constitución de una "economía mundo" europea (Braudel 1984: 8).

Para el caso latinoamericano se ha dejado constancia de los enormes vacíos que "sería apasionante descubrir" (Braudel 1984: 433); en todo caso se ha avanzado en su rol en la conformación de mercados nacionales, regionales, provinciales o locales (Cavieres 1993), en el marco de la articulación de los respectivos Estados nacionales.

En el caso de la ciudad de Santiago, se han estudiado los procesos urbanos de desarrollo y crecimiento (De Ramón 2000); o la relación entre los modelos de organización espacial con sus rasgos socioculturales (De Ramón 2000; Stuardo y Eyzaguirre 1952; Stuardo 1959: 205220; Monclus y Oyon 1982: 432); su carácter o su origen en términos económicos, administrativos o religiosos (De Ramón y Larraín) y el origen e influencias de su estructura (Guarda 1965: 5-105).

Desde el punto de vista de una nueva historia social, la relación ciudad y poder, se ha problematizado en la "urbanidad" y la policía en la ciudad de Concepción entre 1850 y 1880 (Rojas 2011: 443-465); se ha estudiado el damero en cuanto instrumento y representación del orden que se había de implantar en América y como la pieza central de un sistema particular de "producción" y distribución de poder y de sentidos (Durston 1994: 59-115).

Otra arista de trabajo, ha sido identificar la emergencia del "movimiento popular". Desde una perspectiva política y reivindicativa del mundo popular del Chile decimonónico", se ha construido un cuadro general del desarrollo de las luchas y de las organizaciones de los artesanos, peones y obreros urbanos en Chile durante el período 1810-1890 (Grez 1997: 32, passim), y en el marco de una asimetría política entre el sistema político administrativo y el "movimiento social", los motines y protesta han sido presentados como los antecedentes del movimiento social del siglo XIX. La opresión y la explotación, pueden explicar aisladamente la huelga, protesta, el motín y también formas de resistencia como la indisciplina laboral, emigración, nomadismo, rebeldía individual peonal, el bandidismo, la delincuencia o la simple desmoralización (Grez 1997).

Pero la particularidad del movimiento social es que posee una identidad "de clase" y en función de ella, es posible constatar la búsqueda de ciertos objetivos (Grez 1997). Por eso mismo, quizá, no se ha querido ver más que vestigios de turba urbana1. Y sobre todo a partir de 1830, las estrategias represivas consisten en la reorganización de la Guardia Cívica, el sistema de trabajos forzados,

De hecho, el propio Grez señala citando a Hobsbawm, (1983: especialmente, Capítulo V: La turba urbana, p. 165 a 190, pero también p. $9,17,18,40,312,107)$, la turba urbana es “...el movimiento de todas las clases urbanas pobres encaminadas al logro de cambios políticos o económicos mediante la acción directa ---es decir, por el motín o la rebelión--, pero un movimiento que todavía no estaba inspirado por ninguna ideología específica" (Grez 1997: 167 a 168). 
una nueva institucionalidad carcelaria, pena de azotes y palos, control de la mendicidad y el control sobre las licencias (Grez 1997: 224).

En efecto, en esta relación con el poder, la ciudad se ha presentado como un ámbito de represión social y, al menos durante la primera mitad del siglo XIX, permite cuantificar y tipificar el delito femenino en la ciudad de Santiago de Chile (Neira 2002: 119-338), también verificar el tipo de castigo "correccional" referido a las mujeres en la ciudad de Santiago (Neira 2005: 367-390) o explicar aspectos relacionados a la aplicación del Reglamento de Policía en ciudades periféricas como Valdivia en la década de 1830 (Neira y Aguilef 2011: 133-146); o incluso, analizar el levantamiento de estrategias de poder como la delación en Santiago, también durante la primera mitad del siglo XIX (Neira 2014: 39-56),

Desde el punto de vista de la relación ciudadpoder, el modelo de damero no ha pasado inadvertido. Ordena y controla el sujeto espacialmente. Pero sobre todo disuade, cuando permite desplegar un sistema de vigilancia y control y el "delincuente" o transgresor, entonces, debe realizar el cálculo coste-beneficio de su acción (Foucault 1998: 22 y 62).

Sin embargo, más allá del principio utilitarista que sugiere Foucault, toda sociedad oprime a los hombres. La pregunta intelectual es, entonces, ¿cómo la sociedad de la ciudad de Santiago de Chile de la primera mitad del siglo XIX fue opresiva?

Como señala Simón Collier, las medidas represivas son una realidad en Chile, por lo menos antes de la coyuntura de 1861 (1989: 115-
126). Esta represión política ha sido explicada por la actividad policial. Y la historia policial en Chile está bien documentada desde el punto de vista de la descripción y evolución del sistema. En este contexto, los cuarteles urbanos han sido mencionados como una parte más del sistema implementado durante la primera mitad del siglo XIX (Galdames 1903; Urzúa 1936; Bascuñán y Avila 1941; Tobar 1951; Escala 1975; Escala 1978; Escala 1980; Peri 1982: Vols. I y II; Jimenez 1986; Hernandez y Salazar 1994, 3 Vols., I: 5; Lösing 1996: 381-404; Aguila y Maldonado 1996: 73-98; Waldman 1996: 362; Miranda 1997; Rosales 2000: 16). Sin embargo, a esta represión política, se une una "represión cotidiana" que, como reconoce el propio Collier, ha sido escasamente estudiada (Collier 1989: 115-126). En relación a lo mismo, Richard Morse generaliza para Latinoamérica acontecimientos de violencia del pueblo, señalado que,

\footnotetext{
(...) especialmente durante los levantamientos independentistas, se produjo una distensión del control social que alentó a los sectores urbanos más pobres a adoptar actitudes contumaces contra la autoridad constituida (Morse, 2003: 36).
}

La existencia de una represión de tipo "sistémica" aunque de "baja intensidad", digamos, cotidiana como sugiere Collier para el caso chileno o en referencia a la "rebeldía ocasional" del pueblo como sostiene Morse, permiten la posibilidad de generar hipótesis para la comprensión del fenómeno. Este es el marco donde el "damero" se constituye en uno de los referentes más poderosos del discurso de orden y poder (Sáenz 2015).

A partir de la convicción de una represión sistemática desde 1830, el presente trabajo estudia la relación entre el trazado urbano de la ciudad de Santiago de la primera mitad del siglo 
XIX y unas particulares estrategias de poder que se articulan a partir de aspectos ideológicos y de práctica política, configurando de este modo, unas particulares prácticas sociales represivas.

El nivel ideológico es el ámbito de los modelos o "arquitectura" de ideas y modos de organizar la sociedad. En este sentido, una ideología o doctrina, es primero que todo y en último término un concepto de sociedad determinada y el esfuerzo por pensar esa misma sociedad en sus partes. Desde aquí se explica la construcción del proyecto de Estado nacional de las ex colonias hispanas durante la primera mitad de siglo XIX; es el ámbito de acción de un pequeño grupo de hombres poderosos o vinculados de muchos modos al poder que piensan y elaboran un conjunto de representaciones simbólicas, visiones valóricas, opiniones, incluso lugares comunes que luego operan en la realidad. Es una élite que se permite pensar la sociedad, los modelos y formas institucionales que la rigen. $Y$ junto al gran proyecto que es el Estado nacional que es o se pretende liberal, se diseñan también las estrategias y tácticas que aseguren ese cometido.

En este último caso, se trata del nivel de práctica política. Entre otros aspectos, aquí se concibe la organización policial, el aparato que administra justicia y los distintos tipos de castigos. Esto es posible gracias a que el "aparato ideológico" define lo normativo, lo institucional y también lo represivo; pero no explica la articulación de estas ideas en la sociedad, en la realidad. En Chile desde 1830, como señala Simón Collier, se observa un efectivo montaje de fuerzas sociales como Iglesia Católica, militares, fuerzas conservadoras (1985: 238-263). Pero también se idearon otros mecanismos de control menos evidentes. Para los patriotas republicanos las estrategias debían responder primero a un criterio de reorganización y control administrativo; luego devino el control político. En este esfuerzo por demarcar y controlar el espacio público y también el privado, se explica la construcción de todo un sistema normativo, de control y por cierto de exclusión y punitivo. La exclusión se remite a la apropiación y desarrollo de un saber primero, moral-religioso y luego moral-cívico. Esto permite que desde el poder se piense al "populacho" en términos de una amenaza; esta "inseguridad social" es una cuestión que también se deja ver desde un diagnóstico que los mismos políticos elaboran. Este diagnóstico, en una palabra, constituye la mirada de la élite. Es una mirada paranoica y escandalizada de los "horrores" de la masa. En cualquier caso, es un fenómeno que no emerge como señala Romero a partir de la segunda mitad del siglo XIX (1990: 268-278); sino en el instante mismo en que un grupo se legitimó en el poder. En Chile probablemente a partir de 1830. Este es el nivel de análisis en que tan bien hace su aporte Grez, identificando el germen de los movimientos sociales en el golpe de los hermanos Carrera (el 15 de noviembre de 1811), en las revueltas preindependencias (1814-1817), en el período de desórdenes sociales (1823-1830) y a partir de 1830 en adelante, en donde se disciplinó al pueblo, reorganizando la Guardia Cívica, se organizó el sistema de trabajos forzados, el establecimiento de una nueva institucionalidad carcelaria y de castigos (eliminación de pena de azotes y palos) y el control de la mendicidad y licencias (Grez, 1997).

Por último, se puede observar la práctica social propiamente tal. En este nivel se implementan ciertas tácticas. En un concepto, es el devenir cotidiano y tiene mucho que ver con el de "vida material" que, siguiendo a Braudel, hace 
referencia al nivel de vida más elemental, una zona de sombra, difícil de observar por la falta de documentación histórica suficiente y que se extiende por debajo del mercado (Braudel 1984: III Vols., passim). Es el lugar de una actividad elemental básica. De lo cotidiano. De la costumbre y la rutina. En consecuencia, este nivel de práctica se caracteriza porque no es el ámbito de acción de la elite, sino precisamente el resultado de la actividad de ella. En consecuencia, es el lugar de la masa anónima. $Y$ desde el punto de vista del poder, de lo punitivo. Incluso, más bien del que resiste que del protagonista. Aunque la cobertura de los sistemas de control actúa en toda la sociedad, antes que todo tiene un efecto en los gobernados en general y muy especialmente sobre los enemigos políticos o los "enemigos de la sociedad". Definitivamente, en este nivel de vida cotidiana tiene lugar lo represivo propiamente tal (Neira 2004: 285-313). Tratar de entender este nivel significa asumir que lo represivo puede estar compuesto por la actividad policial, judicial y penal. En este trabajo, abordamos la práctica policial solamente.

Teniendo en consideración el ámbito ideológico y la práctica política, la élite chilena de la época encontró un espacio propicio para configurar unas prácticas sociales, interviniendo con éxito en el control de los sujetos por medio de la vigilancia, represión y subordinación². Las

\footnotetext{
La elite a que nos referimos es precisamente la que participa en “...la construcción del célebre 'orden portaliano' (1829-1860) que engendró la más nutrida galería de héroes y hombres ejemplares que haya tenido la historia de Chile; los que, alineados como generación fundadora, han permanecido rampantes y apolíneas, por más de un siglo y medio, en el partenón histórico de la nación" (Salazar 2009: 7). Esta es la elite a la que nos referimos, literalmente, la entenderemos como un grupo de dirigentes, como dice Salazar de mercaderes, empresarios y capitalista de Chile del siglo XIX; a la que también es necesario agregar a militares e intelectuales, en general, vinculados familiarmente.
}

prácticas de poder, al objetivarse en la realidad, tienen efectos sobre los gobernados. Lo que busca comprender este trabajo es, cómo se despliegan las estrategias de poder, es decir, cómo se vigila, reprime y subordina.

Hipotéticamente la trama urbana de la ciudad de Santiago de Chile durante la primera mitad del siglo XIX, se relacionó con una particular ideología de la inseguridad; también con una disposición espacial en que el "plano de damero" permitió la constitución de "cuarteles", que objetivaron un inventario de estrategias o prácticas políticas propiamente urbanas (cobro de impuestos, aseo urbano, funcionamiento y el control institucional y de organizaciones sociales), pero sobre todo, permitió estrategias policiales para el control de la población.

Desde el punto de vista metodológico, el trabajo realizó un seguimiento longitudinal de fuentes en función de las ya mencionadas dimensión ideológica, práctica política y práctica social del objeto de estudio:

Dimensión ideológica. En primer lugar se trabajó las Sesiones de Los Cuerpos Legislativos (SCL), entre el año 1810 y 1845; fueron revisadas más de 3.500 reuniones contenidas en el repositorio digital abierto "wikisource"3; en relación al plano urbano de Santiago, se consideró el diseñado por Claudio Gay, como se observa en la figura $\mathrm{N}^{\circ} 1$.

\footnotetext{
Las Sesiones de los Cuerpos Lejislativos de la República de Chile, se encuentran en Wikisource, La Biblioteca Libre, https:// es.wikisource.org/wiki/Sesiones_de_los_Cuerpos_Lejislativos_ de_la_Rep\%C3\%BAblica_de_Chile_(1810-1845) (consultado el noviembre 20, 2015). Estas fuentes fueron sometidas a un proceso de crítica interna, contraponiendo el volumen de Sesiones de los Cuerpos Legislativos de la República de Chile. 1811 a 1845 , Tomo II, Senado conservador, 1919-1920, Santiago, Imprenta Cervantes, 1887 , de propiedad del autor del presente trabajo.
} 
Figura 1: Plano de Santiago en 1830

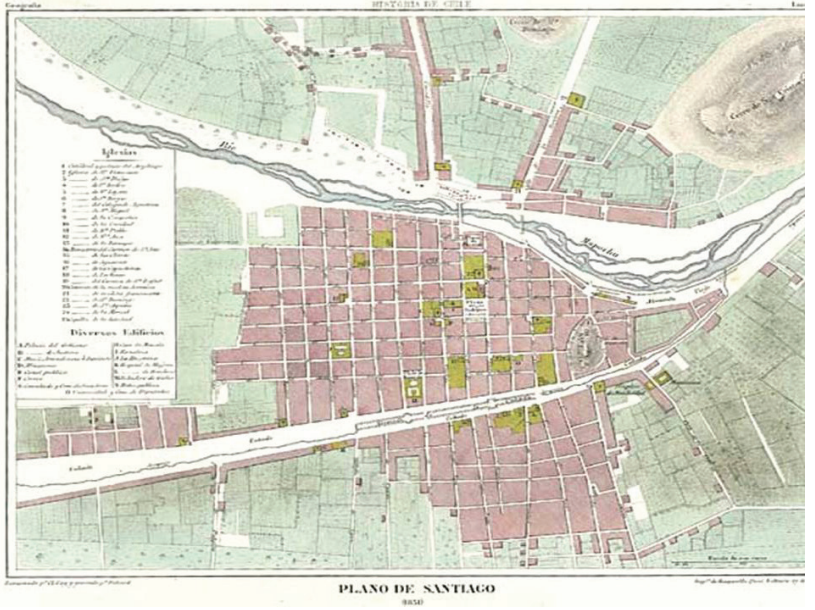

Fuente: Claudio Gay, grabado por Erhard, Impre de Kaeppelin Quai Voltaire 17, á Paris, en Claudio Gay, Atlas de la Historia Física y política de Chile, Imprenta de E. Thunot y Cia., Paris, 1854, s/p.

Dimensión de "práctica política". Se verificaron varias leyes como Ley $\mathrm{V}$, contenida en la Novísima Recopilación de las leyes de España4; leyes chilenas recolectadas por Manuel Valdes $\mathrm{Viji}^{5}$; leyes impresas como el "Reglamento de la compañía vigilante de policía"6; también se utilizó el "Boletín de las Ordenanzas i disposiciones vijentes de policía, dictadas para el servicio local de la Ciudad de Santiago", entre el año 1830 a 18607; se usó

Novísima recopilación de las leyes de España: dividida en XII libros, mandada formar por el señor don Carlos IV. Madrid: Imprenta s.n., 1805, 6 vols.: 339 a 341.

5 Manuel Valdes Vijil, Recopilación de las Leyes, Ordenanzas, Reglamentos i demás disposiciones de policía vijentes en el Departamento de Santiago, Imprenta de "El Independiente", Santiago, 1870.

6 Sin ciudad de edición, Imprenta La Opinión, 30 de junio de 1830. dictadas para el servicio local de la Ciudad de Santiago, desde el año 1830 hasta el $1^{\circ}$ de enero de 1860 , Imprenta chilena, Santiago, 1860.

igualmente el volumen "Leyes promulgadas en Chile, desde 1810 hasta el $1^{\circ}$ de junio de $1912 " 8$.

\section{Dimensión de "práctica social" o "vida} cotidiana". Se trabajó una muestra de arrestos y "penas correccionales" utilizando los Libros de Condenas de la policía urbana de Santiago (LC). Una base de datos de más 40.000 registros de detenciones de sujetos transgresores realizados por la policía de Santiago entre 1830 y 1840. Este registro posee una regularidad de 10 años continuos, exceptuando el año 1835. Y de acuerdo al "Reglamento de la Compañía Vijilante de Policía" (Imprenta La Opinión, 30 de junio de 1830), corresponde a uno de los tres libros administrados por el Alcalde de Barrio o Subdelegado. Los LC, permitieron una muestra intencionada. La muestra contempló un caso de arresto policial por mes, siguiendo la lógica de una muestra intencionada. Los años escogidos fueron: 1830, 1831, 1837 y 1838. Cada uno de estos registros policiales aporta el nombre del individuo arrestado, el delito o conducta transgresora, algún agravante cuando correspondía y su castigo o si debido a la gravedad de las imputaciones debía pasar al Juez del Crimen.

Por cada año, se eligió un delito cada mes, con el objeto identificar en la práctica misma, los efectos de un verdadero proceso que involucró desde la idea de Orden público, la noción de cuadrantes, pasando por una variedad de prácticas políticas que impusieron estrategias represivas.
Leyes promulgadas en Chile, Desde 1810 hasta el $1^{\circ}$ de junio de 1912, Imprenta, Litografía y Encuadernación Barcelona, Santiago, 3 vols., vol. I 1810-1854. 
Se ha mantenido la ortografía de la época en todas las citas textuales y también en los nombres de los sujetos.

El desarrollo del trabajo se estructura en tres apartados a partir del siguiente detalle: a la presente introducción, se agregan, 1.- Aspectos ideológicos:1.1OrdenPúblico, 1.2Delacuadrícula al cuartel, 1.2.1 Periodo colonial, 1.2.2 Periodo republicano. 2.- Práctica Política: 2.1 Estrategias en torno a los cuadrantes, 2.2 Funcionamiento urbano general, 2.2.1 Cobro de impuestos 2.2.2 Aseo urbano, 2.2.3 Funcionamiento institucional, 2.2.4 Organizaciones sociales, 2.2.5 Especificidad policial: la Intendencia y control de la población y 3.- Práctica social: impacto sobre la vida cotidiana.

\section{Aspectos ideológicos}

\subsection{Orden Público}

La "Independencia política" y el proceso de construcción republicano, empujaron a las elites del naciente Estado chileno a conformar una carta fundamental. La Constitución debió ser un aporte y pudo ser igualmente un esfuerzo por compilar una serie de ideas, definiciones y probablemente acuerdos de la dirigencia local. El positivismo dominante en la época impuso de manera categórica la idea que la ley podía cambiar las costumbres. Por eso se gobernó atropelladamente por medio de leyes, órdenes y bandos, entre otras. Para el caso de las Constituciones, no obstante, su carácter abstracto determinó un reducido efecto sobre los gobernados y sobre muchos de los propios gobernantes. Se sabe que un político tan importante como Diego Portales demostró una actitud displicente frente a la Constitución de 1833. Incluso Góngora llega a decir que a Portales la Constitución "le importaba poco" (Góngora1998: 57). Lo cierto es que el ministro Portales puso en duda la efectividad de las Constituciones y leyes en general, puesto que la mayoría de tan nobles y altruistas principios, según señalaba, tenían escasa aplicación. En carta a su amigo Antonio Garfias, Portales dejó señalado,

\begin{abstract}
¿Para que carajos sirven las Constituciones y papeles, si son incapaces de poner remedio a un mal que se sabe que existe, que se va a producir y que no puede conjurarse de antemano, tomando las medidas que pueden cortarla? Pues es preciso esperar que el delito sea infraganti ${ }^{9}$.
\end{abstract}

En desmedro de las Constituciones, las simples leyes impactaron de manera más directa a la población.

Y junto a las leyes, la idea de Orden Público probablemente fue determinante para la legitimidad de la autoridad, la seguridad social y tuvo enormes consecuencias a nivel de vida cotidiana. En España, todavía hacia 1812, seguía vigente el Orden Público del Antiguo Régimen. Esto es, el de un Estado absolutista concebido como un mecanismo para defender el poder. Este Orden Público consistió en “...una imposición del Estado a los ciudadanos por el que les procuraba cierta seguridad a cambio de adaptar su conducta a las normas establecidas" (Iglesias 2010: 373-402, específicamente, p. 380).

En Chile, durante la primera mitad del siglo XIX la aplicación del Orden Público alcanzó el sentido original ya señalado. $Y$ como en la propia España, estuvo contenido en la Ley $\mathrm{V}$ de la

Diego Portales, Carta a Antonio Garfias, en Raúl Silva, Ideas y confesiones de Portales Santiago, Editorial del Pacifico, 1954, 57. 
Novisima Recopilación. Básicamente pretendió el control de la población. Fue un catálogo de acciones prescriptivas, frente también a un catálogo de eventuales desórdenes sociales. Se trató de un conjunto de,

(...) leyes preventivas de los bullicios i conmociones populares...[que debían imponerse]...a los que resulten reos, las penas que prescriben en sus personas i bienes ${ }^{10}$

El Orden Público incluso fue citado en los cuatro últimos documentos constitucionales chilenos de la primera mitad del siglo $\mathrm{XIX}^{11}$. Pero lo verdaderamente relevante en el Orden Público, va a ser su impacto sobre la práctica política y específicamente, sobre la vida cotidiana. Y todo esto se ve complementado por una creciente, aunque desordenada cantidad de decretos, leyes y bandos que prohíben todo o casi todo. En rigor, el Orden Público transitó transversalmente desde un nivel ideológico, pasando por la toma de decisiones políticas hasta el de la realidad social misma, dado sus efectos sociales en materia represiva. Yaunque se pueden encontrar antecedentes de fenómenos similares durante el periodo colonial, desde fines de la década de 1810, pero sobre todo desde 1830, en Chile se observa un verdadero proceso donde se intentó controlar incluso la vida diaria de las personas.

10 Ley V. Novísima recopilación de las leyes de España: dividida en XII libros, mandada formar por el señor don Carlos IV. Madrid: Imprenta s.n., 1805.

11 El Orden Público se introduce por primera vez en la carta fundamental de 1822, en el Capítulo II, en el Artículo 106. Posteriormente en la de 1823, en el Art. 151, en el punto 6 y en el Artículo 201, en el punto 1. Mientras que en la Constitución de 1828, en el fue citada en el Artículo 119, en el punto 2. Y en la Constitución de 1833, finalmente, en el Capítulo VII, en su Artículo 81; también en el apartado que "Corresponde a las Municipalidades en su territorio", en el Artículo 129.
La noción de Orden Público que contuvo la Ley $\mathrm{V}$, ofreció un verdadero programa que siguieron las autoridades locales. Y lo que es más importante, a través de la acción policial, ese mismo Orden Público logró una alta eficacia apoyado en el plano urbano y principalmente en la distribución espacial de los cuarteles que, en último término, permitieron la instalación de agentes, agencias, protocolos y estrategias policiales.

\subsection{De la cuadrícula al cuartel}

2.2.1. Periodo colonial. De acuerdo a Alonso Ovalle, la planta de la ciudad de Santiago en 1640, permitió que

...de cualquier efquina, en que vn hombre fe ponga; ve quatro calles vna al Oriente; otra al Occidente, y las otras dos, a feptentrion, y a medio dia; y por cualquiera de ellas tiene la vifta libre...12.

En efecto, el modelo urbano traído por los españoles a los nuevos territorios fue el de damero. Se han encontrado vestigios en Babilonia ${ }^{13}$; en campamentos militares romanos, como las "Bastides" (villas fortificadas), en Francia; en la ciudad de Santa Fé, España (Morse 1962: 317-338); o también en ciudades españolas relacionadas a ideas medievales de la "ciudad ideal" de San Agustín (Guarda 1965: 5-29; Kagan 1997: 51-86). De todas maneras, esta forma urbana se institucionalizó en la ley española, pasó a las Colonias y se desarrolló en las nuevas repúblicas.

12 Alonso De Ovalle, Histórica relación del Reyno de Chile, Francisco Caualo, Roma, 1646, p. 152.

13 Heródoto, Los nueve libros de la Historia. Buenos Aires, El Ateneo, 1961 , p. 101 
Sobre el cuadriculado que observó Ovalle, durante el gobierno de Antonio Guill y Gonzaga, el 12 de febrero de 1764, se promulgó un decreto real que dejó dividida la ciudad de Santiago en cuatro sectores (véase FIGURA N $\left.{ }^{\circ} 2\right)^{14}$.

Figura 2: Plano de Santiago en que se ha superpuesto los cuadrantes del Decreto Real, 12 de febrero de $1764^{15}$

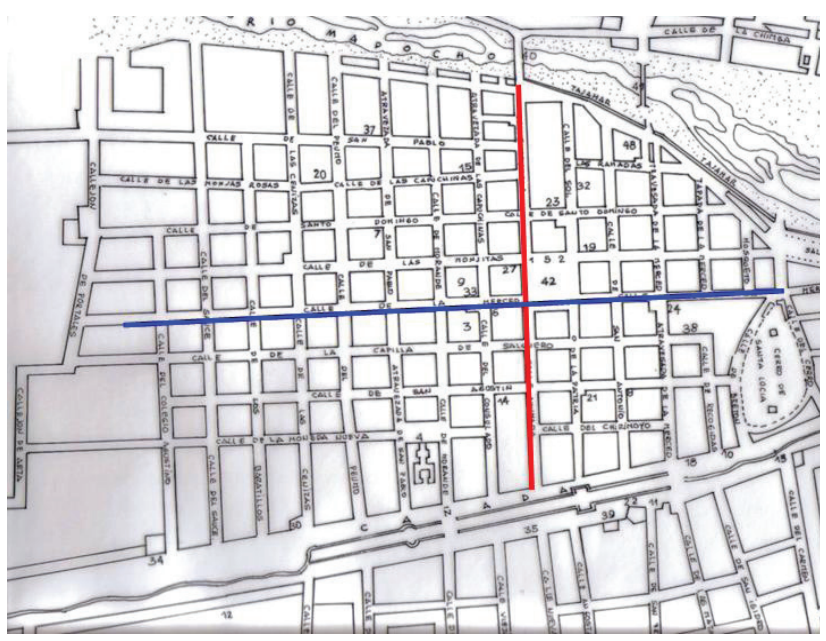

Las únicas coordenadas de norte a sur, fueron el eje de las calles Puente-Ahumada y de oriente a poniente el eje Merced-Compañía. El cuadrante Puente/Merced, correspondió al cuartel $N^{\circ} 1$; el cuadrante Merced-Ahumada, correspondió al cuartel $\mathrm{N}^{\circ}$ 3; el cuadrante Ahumada/Compañía, correspondió al cuartel $\mathrm{N}^{\circ} 4$; el cuadrante de

14 Decreto Real, 12 de febrero de 1764, en Juan Tramaya y Ricci, Catálogo cronológico de las pragmáticas, cédulas y órdenes, $\mathrm{S} / \mathrm{A}$, Boletín oficial recopilado, Colección completa de leyes, decretos, reales ordenes y reglamentos relativos a la organización y atribuciones de las municipalidades v.1, 2, 3 y 4, Buenos Aires, 1978, Tomo tercero de autoacordados de 1723 a 1745.

15 Reproducción propia del Plano de Santiago levantado por Claudio Gay.
Compañía, Compañía/Puente, dio origen al cuartel $\mathrm{N}^{\circ} 2$. La racionalidad de esta división se mantuvo a través de los años. En la medida que la ciudad comenzó a extenderse en el espacio y en el tiempo, este criterio inevitablemente también se fue extendiendo y efectivamente se transfirió al período republicano.

En el año 1778, las coordenadas sobre la planta física de la ciudad se definieron en términos similares. De acuerdo a un documento de la época,

Habiendo manifestado la experiencia, que no hai medio mas expedito para facilitar en las Ciudades populosas la pronta y recta administración de Justicia, i asegurar en ella la paz, i tranquilidad política que deven regir entre los Ciudadanos, que el de distribuirlas en Quarteles y subdividir estas, en barrios a cargo i direccion de sus respectivos Alcaldes, y hallandose por tan poderosos motivos recomendado este util extablecimiento en varias leyes de España ino solo gloriosamente mencionado y restablecido por el paternal desvelo de Nuestro Augusto Soberano en su Real Corte, sino mandado extender por su Real cedula de 13 de Agosto de 1760 a las demas ciudades Capitales de España donde nuestra Audiencia o Chancillería. Deseando esta Real Audiencia gobernado concurrencia por su parte a las benéficas intensiones de Su Magestad después de haver hecho procuradamente la división de esta Capital en quatro Cuarteles asignado a cada cual Sr. Ministro que le gobernace i diriguiese para señalarse ahora con toda distinción y claridad las funciones i facultades de los Alcaldes de Barrio $y$, precaverse de esta manera las disputas i Odiosas competencias que pudieran subscitarse con las Justicias Ordinarias, malograndose quizás por este medio los saludables efectos de su institución ${ }^{16}$.

Instrucción de el ministerio y facultades de los alcaldes de barrio mandadas crear por artículo $6^{\mathrm{a}}$ de el Auto acordado de esta Real Audiencia de 17 de agosto del año de 1778, en Portal Memoria Chilena, URL., http://www.memoriachilena.cl/archivos2/pdfs/ MC0052556.pdf, 10 de mayo de 2011). La existencia de esta subdivisión es corroborada por Vicuña Mackenna, quien confirma que en 1780 Santiago posee la misma división (Benjamín Vicuña Mackenna, Historia crítica y social de la ciudad de Santiago desde su fundación hasta nuestros días (1541 - 1858). Valparaíso, Imprenta del Mercurio, 1869, varios Vols., Vol. II, p. 41). 
La Novíssima Recopilación, consignó expresamente que la fundación de ciudades debía tener en consideración un catálogo de medidas orientadas a salvaguardar un especial ordenamiento urbano:

En cada quartel se establecerán ocho Alcaldes de barrio con este nombre, que sean vecinos honrados; y su elección se executará por quarteles en la misma conformidad que la de los comisarios electores de los Diputados y Personeros del Comun; los quarteles subdividirán entre el distrito de su quartel, y matricularán todos los vecinos, y los entrantes y los salientes, celando la policía, el alumbrado, la limpieza de las calles y de las fuentes: atenderán á la quietud y órden público $(\ldots)^{17}$.

En suma, teniendo como base de la cuadrícula de la ciudad, a fines de siglo XVIII se había configurado la noción de cuartel. Y a comienzos del siglo XIX, el Orden Público aparece adscrito a la organización de esos cuarteles.

2.2.2 Periodo republicano. Todavía en 1844, por ejemplo, queriendo salvaguardar las determinaciones que debían guiar la construcción de toda nueva ciudad en Chile, un decreto insistió en la necesidad de seguir la lógica del cuadriculado ${ }^{18}$.

Desde el punto de vista de la estructura urbana, esto no tendría demasiada novedad. En cambio, se han encontrado vestigios de la existencia de la noción de cuarteles en la ciudad de Santiago, en una serie temporalmente irregular de ordenanzas de policía durante la primera mitad del siglo XIX.

Novísima recopilación de las leyes de España, ya citada,p. 525.

18 "La plaza maior de toda nueva población se establecerá de manera que partan dos calles principales por cada una de sus cuatro esquinas formando acera derecha con la misma plaza i con la calle que se halle a la misma línea en la esquina de enfrente" (Decreto supremo de 4 de enero de 1844, en Manuel Valdes Vijil, Recopilación de las Leyes, Ordenanzas, Reglamentos i demás disposiciones de policía vijentes en el Departamento de Santiago, Imprenta de "El Independiente", Santiago, 1870 (Rec. Realizada por Osvaldo Rengifo y Alberto C. Patiño), p. 105).
En 1817, un reglamento de "vigilantes" dividió la ciudad de Santiago en ocho cuarteles ${ }^{19}$. Luego, en 1830 la "policía urbana" igualmente dividió la ciudad de Santiago en cuatro cuarteles ${ }^{20}$. Y todavía, la "Sección de Infantería" en 1862, también suscribíó la lógica de cuatro cuarteles²1. Aun en 1863 la "Sección de Caballería de la

19 Según un decreto de policía, "Los Quarteles 1, 2, 3 y 4, se comprehenden un un triangulo cuyo vertise es la chacra del prebendado Herrera: su base una línea recta tirada desde el rio á la cañada, atravesando los molinos de Portales; y sus lados, por el norte el rio Mapocho, y por el sud, la acequia de la cañada () Una línea recta tirada desde las casas de la chacara de Herrera siguiendo la Alameda, calle de la Merced y Compañía hasta tocar en la base señalada anteriormente: y otra línea asi mismo recta tirada desde el pie del puente por la misma calle del puente y Ahumada hasta tocar en la esquina de Pedregal en la cañada, dividen este triangulo en quatro partes que son los quatro quarteles referidos (Policia Urbana, Vigilantes, 1817, "Distribución de los 8 Quarteles en que está dividida la ciudad de Santiago", Acápite Quarteles, en Semanario de policía, 3 (miércoles 17 de septiembre de 1817), Primer año, 1-2).

20 De acuerdo al documento que consignó la información, Cuartel $1^{\circ}$ La población comprendida entre la vereda norte de la calle de la Merced hasta la esquina de Palacio arzobispal; la vereda oriente de la calle del puente hasta el tajamar i la pila que se encuentra a espaldas del Reñidero de Gallos ( ) Cuartel $2^{\circ}$ La población comprendida entre la acera norte de la calle de la Compañía, la acera poniente de la calle del puente, desde la esquina de Palacio arzobispal; la márjen izquierda del Mapocho i ambas aceras de la calle de Negrete () Cuartel $3^{\circ}$ La población comprendida entre la acera sur de la Merced desde la esquina poniente del portal de Sierra Bella, las cajitas de agua; ambas aceras de la alameda principal i la acera oriente de la calle Ahumada ( ) Cuartel $4^{\circ}$ La población comprendida entre la acera sur de la calle de la Compañia; la acera poniente de la calle Ahumada, ambas aceras de la alameda principal hasta la alameda de Matucana i ambas aceras de la calle de Negrete (Cuarteles, División de Santiago en 1830, en Boletín de las Ordenanzas i disposiciones vijentes de policía, dictadas para el servicio local de la Ciudad de Santiago, desde el año 1830 hasta el $1^{\circ}$ de enero de 1860, Santiago, Imprenta chilena, 1860, p. 141-142.

21 "El primer cuartel se ubicó al sur, desde la calle de la Merced, por el norte el Tajamar, al oriente la Cancha de gallos o la calle de los Tres Montes y al poniente calle Bandera (...) El segundo cuartel desde la cañada, hasta la calle de la Merced, al oriente la calle de Breton y al poniente la acera de la calle Bandera ( ) El tercer cuartel, desde la Cañada, al norte hasta la calle Compañía, oriente la calle Bandera y al poniente la calle de los Baratillos (...) El cuarto Cuartel, por el sur la Calle de la Compañía, por el norte hasta Tajamar, al oriente hasta la calle de la Bandera y al poniente la calle de los Baratillos" (Sección Infantería, Decreto 3 de febrero de 1862, en Manuel Valdés Vijil ya citado, p. 24). 
Guardia Municipal" adoptó también los cuarteles distribuyendo su fuerza en cinco de ellos22.

Y todavía en 1868, la "Inspección de Policía urbana", organismo encargado del orden, aseo y equipamiento urbano, dividió la ciudad de Santiago en cuatro cuarteles para atender este servicio ${ }^{23}$.

Las cuadras, en fin, fueron una realidad sobre la que las ciudades se desarrollaron como el caso de Santiago de Chile. Pero el entramado de damero también fue utilizado por el poder para establecer los cuarteles de policía urbana.

22 "El Primer cuartel, al oriente tuvo como límite las Cajitas de Agua; al norte, el Tajamar; al poniente, el Reñidero de Gallos i la calle de Breton; y al sur, la acera de la Cañada (...) El Segundo cuartel, ubicado al oriente, el callejón de la 'Ollería'; al norte, la acera de la Cañada; al poniente, la acera de la calle vieja de San Diego y al sur el canal de San Miguel (...) El Tercer Cuartel ubicado a oriente, limita la calle vieja de San Diego, al norte la acera de la Cañada hasta la calle de Castro; al poniente, la calle de Castro y al sur el canal de San Miguel (...) El Cuarto Cuartel, ubicado al oriente con límite la calle de los Baratillos; al norte, la rivera de Mapocho; al poniente, la Alameda de Matucana y al sur, la acera de la Cañada hasta el Colegio de Agustinos y desde allí hasta la estación de ferrocarriles y la Alameda de las Delicias (...) El Quinto Cuartel, comprende los barrios de la Chimba y Cañadilla" (Guardia municipal, sección Caballería, Decreto 24 de noviembre de 1863, en Valdés, p. 24).

23 El primer Cuartel, tuvo por límites al oriente las Cajitas de agua, al Poniente la Calle de Negrete, al Norte la calle de San Pablo y las ramadas y por el sur, la calle de las Delicias. El Segundo Cuartel, limitó por el oriente con la calle de Pedregal, siguiendo una línea hasta el "Sanjón de la Aguada", por el poniente, con la calle del "Dieziocho" y San Ignacio inclusive, por el norte con la calle de las Delicias y por el sur con el Zanjón de la Aguada. El Tercer Cuartel de Yungay, iba por el oriente desde la calle de Negrete inclusive y calle Dieciocho y San Ignacio inclusive, al poniente con calle de la Estación y Alameda de Matucana, por el norte con el canal de Zapata y por el Sur, con el Zanjón de la Aguada. El Cuarto Cuartel del Norte, extendía sus límites por el oriente con la calle de la Purísima y puente del mismo nombre, por el poniente con el callejón de "Las Hornillas", por el norte, los callejones de Carrión, Cementerio y Domínica y por el sur, con las calles de Tajamar, Ramadas y San Pablo (Acuerdo Municipal, Supremo Decreto 24 de agosto de 1868, en Valdés, p. 31-32).
A partir de coordenadas abstractas, los cuarteles devienen en una sectorización de la ciudad. Sobre esta base se instaló una red institucional destinada a la vigilancia, control y castigo social. Más fuertemente configurada en el centro y más débil en la periferia de la ciudad, en los arrabales $y$ en el sector rural. Aunque en el sector rural también se puede encontrar un rayado de poder. En el contorno del plano urbano y más allá también existe un entramado que intentó controlar el campo circundante. El sistema judicial, por ejemplo, estableció que "los jueces de campo" tuvieran especies de comarcas sometidas a su control. Pero en la práctica tales asignaciones resultaban inútiles y se volvían precarias, debido a las grandes extensiones que abarcaron, también a lo escaso de los recursos policiales, pero sobre todo a las múltiples superposiciones jurisdiccionales (Cobos 1980: 85-166).

En consecuencia, desde su fundación y siguiendo la lógica del modelo "de damero", las ciudades latinoamericanas fueron progresivamente atravesadas por líneas invisibles que demarcaron un determinado número de zonas, delimitando territorios con el objeto de verificar su contenido material y humano como se verá.

El discurso del Orden público de raigambre colonial, se constituyó para la elite gobernante en una poderosa herramienta represiva. Entre otros aspectos, operó de espaldas al proclamado liberalismo de comienzos del siglo XIX. $Y$ al involucrar un saber represivo que impactó en la vida cotidiana, terminó mostrando su verdadera cara: se constituyó en una verdadera ideología del miedo y la desconfianza.

El Orden público, en fin, configuró unas prácticas sociales que actuaron a nivel de vida 
cotidiana, precisamente donde los esfuerzos de la elite por disciplinar, controlar y castigar a los grupos subalternos quedan de manifiesto de manera más completa.

\section{Práctica Política}

\subsection{Estrategias en torno a los cuadrantes}

Desde fines del siglo XVIII, pero sobre todo desde la década de 1810, la ciudad de Santiago fue sectorizada en torno una serie de estrategias de poder. Los cuarteles constituyeron una malla invisible que dividió la ciudad, objetivando aspectos ideológicos relacionados a la idea de Orden Público. Dicho de otro modo, a partir del plano urbano, pero sobre todo a partir de la configuración de cuarteles, el poder distribuyó agencias y agentes que trabajaron con objetivos urbanos, municipales, de aseo, pero también de orden, seguridad y sobre todo estrategias represivas.

\subsection{Funcionamiento urbano general}

Los integrantes del cabildo objetivaron las normas bajo las que la institucionalidad más cercana a la población debió funcionar. Los regidores rayaron el plano urbano. $\mathrm{Y}$ al hacerlo, definieron áreas de control segregando en diferentes sentidos. En torno a la "policía de aseo" que operó sobre esta distribución espacial, se observaron diversas funciones como el cobro de impuestos, aseo urbano, control sobre el funcionamiento de las instituciones y las organizaciones sociales.

3.2.1 Cobro de impuestos. La racionalidad de los cuarteles sirvió para definir problemáticas de economía gubernamental o fiscal como el cobro de impuestos ${ }^{24}$. En la reglamentación de los serenos, en 1830, se consignó, por ejemplo, que

Todas las demás casas fuera de este cuadro [o cuadrante] solo pagaran dos reales por puerta, y medio real por quarto: su designación particular señalara por los quatro costados de la ciudad hasta donde deba extenderse por casa con obligacion de pagar $(\ldots)^{25}$.

Una ley destinada a organizar el trabajo de los serenos en 1835, propuso que los "alquiladores" o "habitadores", estaban obligados a pagar dicho gravamen y el "mantenimiento del alumbrado público", obligando igualmente a que, "(...) solo en el caso de estar aquellas inhabitadas deberá recaer esta obligación sobre los propietarios"26.

El Intendente de Santiago debía "convenir" a los arrendadores morosos el pago de las cantidades que adeudaban, “...ejecutándolos por medio de la fuerza sino se manifiestan dóciles al primer requerimiento..."27.

3.2.2 Aseo urbano. Los cuadrantes igualmente, sirvieron para efectuar la planificación,

24 En la reglamentación de los serenos, en 1830, se consignó, por ejemplo, que "Todas las demás casas fuera de este cuadro [o cuadrante] solo pagaran dos reales por puerta, y medio real por quarto: su designación particular señalara por los quatro costados de la ciudad hasta donde deba extenderse por casa con obligacion de pagar..." (Decreto del gobernador del departamento de Santiago al Cabildo de Santiago, Libro de acuerdo de esta Municipalidad de Santiago de Chile, 1830-1832, Fondo Cabildo de Santiago, Archivo Nacional, Vol. 94, fs. 6 y 6vta.).

25 Decreto del gobernador del departamento de Santiago al Cabildo de Santiago, Libro de acuerdo de esta Municipalidad de Santiago de Chile, 1830-1832, Fondo Cabildo de Santiago, Archivo Nacional, Vol. 94, fs. 6 y 6 vta.

26 Diego Portales, Serenos, en Boletín de las Leyes y de las Ordenes y Decretos del Gobierno 1846, Tomo segundo, libros V, VI, y VII: 393-394.

27 Serenos, Santiago, diciembre 29 de 1835, en Bolethn de las leyes y de las yrdenes y decretos del Gobierno, Valparaíso, Imprenta de Mercurio, 1846, Tomo segundo, que contiene los libros V, VI, y VII, 393-394. 
organización y ejecución de tareas propias o estrictamente urbanas como el aseo. Rudecindo Ramos, un vecino interesado en su administración, a comienzos de 1830 estimó que para desarrollar tal actividad en la ciudad de Santiago, se debía pagar la cantidad de 50 pesos mensuales por cuartel. Considerando la cantidad de 8 cuarteles, el proyecto sumó 400 pesos. De acuerdo a Ramos,

(...) aseada la poblacion toda, arreglados los puentes y limpias siempre las azequias que crusan las calles atravesadas y rectas, por la cantidad de cincuenta pesos mensuales por quartel que son quatrocientos por los ocho en que se divide $(. . .)^{28}$.

\subsubsection{Funcionamiento institucional. Los} cuarteles incluso facilitaron el ejercicio del control sobre el funcionamiento de algunas o todas las instituciones públicas. El caso del Protomedicato es un buen ejemplo. Dependiente precisamente de la policía de Aseo, el Protomedicato tuvo por objeto la salubridad de la población en el más amplio sentido. El encargado del protomedicato en 1830, informaba al Gobierno que,

Solo basta una ojeada muy superficial sobre el aspecto general de las calles, y un pequeño conocimiento del estado de las acequias y patios interiores de las casas de Santiago para convencerse que la limpieza de la ciudad de Santiago merece la mas formal consideración y la adopcion de los planes mas energicos para su mejoramiento. Con muy escasas excepciones, no hay una calle ni un patio interior que no sea un detestable deposito de bazofia, un repugnante laboratorio en el que por medio de la putrefacción no se despoje al aire de su natural pureza, y á la existencia humana de su goce y duración $(\ldots)^{29}$.

$28 \quad$ R. Ramos, Nota señor Gobernador local, Municipalidad de Santiago, Libro de acuerdo de esta municipalidad de Santiago de Chile, 1832-1832, Fondo Cabildo de Santiago, Archivo Nacional, Vol. 94, fs. 98.

29 M. Carballo, Nota del presidente del Protomedicato al ejecutivo, Santiago, junio 10 de 1830, Cabildo de Santiago, Archivo de la Municipalidad, 1830-1831, Archivo Nacional, Vol. 098, fs. 66 y vta.
Por medio de los cuarteles, la policía urbana pudo controlar ciertos aspectos de la salubridad pública, relacionada a la contaminación domiciliaria, lo que en la época fue un problema de proporciones, dado el uso de las acequias que cruzaban la ciudad en distintas direcciones.

A la estrategia anterior, se une el papel de la milicia o Guardia Nacional. De origen igualmente colonial, la milicia se re-articula a partir de 1825 y se mantiene vigente por lo menos hasta el gobierno de Manuel Bulnes (1845). La organización de las milicias será cuidadosamente regulada por medio de los cuadrantes ${ }^{30}$.

\subsubsection{Organizaciones sociales. Las cuadras y} cuadrantes también permitieron el control sobre la sociabilidad política. Aun cuando durante este período no hay partidos políticos, existen organizaciones como los Clubes, Sociedades o Gremios, por lo que efectivamente hay oposición política. Pero ellos surgen, más bien de la presencia de ciertos líderes (Collier 1982: 143163, específicamente, p. 114) ${ }^{31}$. Sin embargo, a partir de 1849, emergió un fermento social que terminó expresándose en una clara oposición al gobierno. Por eso, desde fines de la década de 1850, toda muestra o síntoma de organización política pudo ser prohibido. Un bando de 1858 en su artículo primero señaló que, "No podrá instalarse en Santiago ninguna sociedad o club

\footnotetext{
SCL, Acta, Sesión del Senado Conservador, 22 de junio de 1824.

31 La enorme influencia y control político de los Intendentes encontró su máxima expresión en la década de 30 . En los procesos de votación, el Intendente, el Gobernador, incluso el subdelegado tendrán un influjo determinante. Esta influencia luego tiende a decaer paulatinamente a partir de la Reforma de 6 de agosto de 1869 (Ley de elecciones, 13 de septiembre de 1861, en Ricardo Anguita, Leyes promulgadas en Chile. Vol II, 114 a 125) por medio de la cual se instalan Juntas Inscriptoras en las Municipalidades, Juntas de Mayores contribuyentes y Juntas revisoras.
} 
político sin permiso especial i concedido por escrito por la Intendencia"32.

En la práctica, la fijación de un domicilio sirvió al poder para movilizar a los policías en la lógica de los cuarteles para el control social. Incluso, la legislación consignó que,

(...) El que contraviniere a la disposicion del articulo precedente, el dueño o arrendatario de casa que las facilitare para las reuniones que quedan prohibidas o el que cooperase para que dichas reuniones tengan efecto, sufrirán las penas que por el artículo 127 de la lei de Réjimen Interior puede imponer esta Intendencia (... $)^{33}$.

La instalación de todo tipo de organización social o política estuvo expresamente prohibida de no mediar autorización del gobierno. Con mucha mayor razón, entonces, fueron vigiladas y perseguidas las actividades políticas opositoras. Al respecto, un decreto de 1850 , señaló que,

Ninguna sociedad o club, cualquiera que sea el número de personas de que se componga, podrá presentarse o salir en cuerpo por las calles o plazas, ni hacer manifestaciones de ningun jénero $(\ldots)^{34}$.

Según el mismo documento, toda actividad política debía ser,

...anunciada a la Intendencia, por los que encabecen o promuevan con un dia de anticipacion a lo menos; señalando el lugar, dia i hora de la reunion, para que, si aquella la tuviese por conveniente, envie ajentes de policía que asistan.

Como consecuencia, las reuniones públicas, igualmente fueron sometidas a un cuidadoso escrutinio. Al respecto, una ordenanza de 1856, señaló que,

32 Bando 12 de diciembre de 1858, en Valdés, p. 40-41.

33 ld.

34 Decreto de a Intendencia fecha 9 de noviembre de 1850, en Manuel Valdés, p. 41
Ninguna persona, reunion de personas o funcionario público, salvo los casos en que las leyes dispongan lo contrario, podrá usar en público, ni enarbolar el estandarte nacional en los edificios públicos o particulares, sin que proceda órden o permiso del Intendente de la provincia, i conformándose en todo a los términos de dicha órden o permiso $(. . .)^{35}$.

En suma, a partir de un aspecto ideológico contenido en la noción de Orden público de raigambre colonial, los administradores políticos actuaron sobre la cuadrícula urbana, sobre el plano de damero y con fines estratégicos se impuso la noción de cuartel, distribuyendo la ciudad en una serie de sectores y esto, permitió el control de ciertas actividades estrictamente urbanas. Lo importante es que la relación Orden público-cuadrículas-cuarteles, igualmente comportará un contenido policial.

\subsubsection{Especificidad policial: la Intendencia y} control de la población. Joaquín Escriche, un legislador conocido en Chile de la primera mitad del siglo XIX, definía la policía como una institución que tenía por objeto la disciplina de las costumbres, la salud pública, el control de los abusos en el comercio, la seguridad y tranquilidad general, la limpieza de las calles, la solidez y hermosura de los edificios y

(...) la observancia de los estatutos, leyes, bandos, ú ordenanzas municipales, la represión de los juegos, del uso de las armas, de la ociosidad ú holgazanería, y de todas aquellas acciones que aunque poco ó nada criminales por sí mismas pueden tener malas resultas ú ocasionar crímenes ó males á los ciudadanos $(\ldots)^{36}$.

A partir de esta amplia definición, se van a configurar a lo menos dos tipos de policía en Chile:

35 Ordenanza 2 de diciembre de 1856, Art. 40, Valdés, p. 61.

36 Joaquín Escriche, Diccionario razonado de legislación y jurisprudencia. París: Librería de Rosa, Bauret y Cía, 1851, p. 1356. 
i.- La "policía de aseo", que debía cuidar "... del abasto público, repartimiento de aguas, aseo i limpieza de la poblacion, carceles, etc., alumbrado i demas funciones peculiares..."37. La "policía de aseo" data por lo menos de 1725 y su dependencia fue directa del cabildo (Vicuña 1869: II, 41). El papel institucional jugado por la policía de aseo fue idéntico al de la "policía de seguridad", solo que sobre los cuarteles actuaron un Inspector y cuatro comisarios con cuadrillas de trabajadores y su papel fue velar por el aseo principalmente.

ii.- La "policía de seguridad" funcionó de día a través de una fuerza regular y de noche a través de los serenos. Pudo arrestar y aplicar algunos castigos. La policía de seguridad, o "alta policía", debía "afianzar el órden público"38. Esta fue una policía represiva y dependió de la Intendencia.

Desde el punto específicamente policial, los cuadrantes constituyen el más exitoso mecanismo de control social. Permiten que el papel policial se despliegue completamente cuando declaran su interés en lograr la seguridad pública en su más amplio sentido, la "defensa y tranquilidad pública", el "bullicio" o "conmoción pública", incluso ciertos problemas específicos como el uso de disfraces o máscaras ${ }^{39}$.

Como una estrategia orientada a lograr las condiciones de seguridad declaradas, el sistema de control alcanzó igualmente el desplazamiento espacial de las personas dentro de la ciudad.

\footnotetext{
37 SCL, Sesión de 7 de diciembre de 1817; "Ordenanza para la policía urbana de Santiago", en Boletín de las Ordenanzas i disposiciones vijentes de policía, dictadas para el servicio local de la Ciudad de Santiago, desde el año 1830 hasta el $1^{\circ}$ de enero de 1860 , Santiago, Imprenta chilena, 1860, p. 141-142.

38 SCL, Anexo núm. 593. V. Sesión del 10 de octubre de 1820.

39 Ley V, ya citada.
}

La legislación consignó un exhaustivo control sobre las llamadas papeletas, boletas 0 salvoconductos. Portar la "papeleta", permitió a un sujeto la movilidad dentro de la ciudad. La ausencia o la simple desactualización del salvoconducto, demostraba al policía que el sujeto poseía la "calidad de vago". Razón por la cual, el detenido era acreedor de "arresto", debiendo desarrollar trabajos públicos. La falsificación del documento, por otra parte, fue igualmente considerada delito. $\mathrm{Y}$ aun cuando el sujeto pudiera haber portado la papeleta, los desórdenes y "ociosidad" justificaban su aprehensión. Precisamente, el objeto principal de la policía fue combatir la "ociosidad", que en opinión de las autoridades era el origen de todos los vicios. El Artículo 11 del reglamento de policía en 1811, dejó expresamente señalado que,

\begin{abstract}
Todo vecino dará noticia al alcalde de qualquier huésped que nuevamente llegue á su casa, y deba mantenerse allí mas de un dia: baxo la pena de dos pesos a los habitantes de quarto, y seis a los de cada omision. Los inquilinos y sirvientes de los hacendados, que llegan de sus haciendas, no se entienden por huéspedes. El que admite en su casa un sirviente sin papel, en que el anterior amo, y en defecto de este el alcalde aquel barrio expongan su conducta, es responsable á las deudas, que haya contraído dicho sirviente con el amo anterior ${ }^{40}$.
\end{abstract}

Aunque el periodo del gobierno de Carrera puede ser poco representativo, igualmente se observa el control sobre el desplazamiento de las personas. Este esfuerzo se expresó en indicaciones a la policía,

(...) previniéndoles que todo individuo que entre á la ciudad, debe presentarse á la Intendencia á las 24 horas de su llegada [o también en el encargo de] (...) espresar en las licencias para salir de la capital, la filiación de

40 Reglamento de policía, sin pie de imprenta, sin ciudad, sin año de edición, Fondo Medina, Biblioteca Nacional de Chile. Según el Semanario de Policía, $N^{\circ} 3$, este documento fue publicado en Santiago en 1811. 
los individuos que las soliciten, y los conocimientos conducentes á dar ideas exactas de la clase de personas ${ }^{41}$.

A fines del año 1819, el cuidadoso control sobre las personas se materializó en un censo que la policía debió efectuar, detallando edad, oficio y clase de habitantes que cada cuartel de la ciudad debía contener. Durante la administración de Bernardo O'Higgins, el Reglamento de los Alcaldes e inspectores de Barrio, consignó en el artículo 11 y 12 que,

Para hacer mas fácil la persecución de los vicios y vagos, hará formar el inspector un recenso general de todo su cuartel, con expresión de la naturaleza, edad, ejercicios, y clase de los habitantes, y siempre que alguno de ellos se mudare á otro barrio deberá dársele por su alcalde respectivo una papeleta que acredite su comportacion y juicio, y no adeudar nada al dueño o propietario de la casa en que vivía, sin cuyo requisito, que deberá presentar al alcalde de barrio adonde piensa mudarse, no podrá ningún propietario admitir inquilino alguno en sus casas, ó posesiones, bajo las penas que en tal caso impondrá asi al propietario, como al inquilino la intendencia, luego que esté cerciorado de hecho respectivo que debe darse, encargándose el cumplimiento de este articulo á la mayor brevedad, y sin omitir persona alguna de cualesquiera clases $(\ldots)^{42}$.

Además de instruir a cada inspector la tarea de levantar un censo en cada cuartel, esta misma ley consignó el control del movimiento de las personas señalando,

Ningun vecino podrá admitir en su casa á persona alguna en clase de alojado, sin dar previo aviso al juez del barrio, bajo la pena que se acordare en fuerza de las circunstancias y clase de alojado. Así, pues, los inspectores cuidarán exactamente de esta resolución, sin que haya la menor falta; llevando un libro por separado, en donde se anotarán el dia en que llegaren á su cuartel algunas personas que

Circular a los Alcaldes y Tenientes, Libro $1^{\circ}$ de 1812 a 1820 , julio 7 de 1813, Libro de acuerdo de esta Municipalidad de Santiago de Chile, 1830-1832, Fondo Cabildo de Santiago, Archivo Nacional, vol. 94 , fs. 4 .

42 Bernardo O'Higgins, Reglamento que deben observar los inspectores y alcaldes de barrio para la mejor administración de justicia, Santiago, Imprenta de Gobierno, septiembre 4 de 1819. vengan de las provincias de afuera, o de otro estado, con expresión de su clase y objeto de su venida, como asi mismo el dia en que salieran para otros destinos.

En atención a estos registros y al manejo de padrones poblacionales de la ciudad, los cuarteles posibilitaron a la policía la revisión pormenorizada de las licencias o pasaportes que debía portar obligatoriamente toda persona ${ }^{43}$.

El Alcalde de Barrio o subdelegado, en 1830, logró injerencia sobre la administración de los cuarteles, llevando un cuidadoso registro de los vecinos de la ciudad por medio de tres libros. En el primero debía anotar el número de las casas, nombre del dueño o del que la habitaba y los recursos que ocupaba para subsistir; en el segundo libro, el policía debía registras los crímenes y robos, el nombre del infractor, su captura o fuga, remitiendo a los aprendidos al "depósito" del Gobernador. En el tercero de los libros, el Alcalde debía anotar "(...) las personas que lleguen á su departamento, bien sea de fuera de la República ó de cualquiera otro punto de ella, como igualmente el objeto de su venida" ${ }^{4}$.

En definitiva, el papel de los Alcaldes de barrio de la policía de seguridad fue el más destacable en materia de prácticas represivas. Su rol tuvo por objeto salvaguardar el Orden Público y su acción estuvo determinada por un catálogo de estrategias de vigilancia apuntadas en la Ley V. Entre ellas, destacan la contabilidad de los

43 Supremo Director, Nota haciendo saber á la Intendencia, que no se permita el uso de pasaporte á individuo alguno particular siempre que en él no se espresen distintamente las señales personales que acrediten ser el mismo sujeto á quien el Gobierno le concedió, julio 7 de 1813, Libro de acuerdo de esta Municipalidad de Santiago de Chile, 1830-1832, Fondo Cabildo de Santiago, Archivo Nacional, vol. 94, Libro $1^{\circ}$ de 1812 a 1820 , febrero 3 de 1815 , fs. 9 .

44 Reglamento de la compañía vigilante de policía (Sin ciudad, Imprenta La Opinión, 30 de junio de 1830), 3; SCL, Anexos № 705 y 706 V., sesiones del 11 y del 22, 19 de junio de 1824 . 
individuos, el control de sus comportamientos y desplazamientos.

Conforme a todo lo señalado anteriormente, las cuadras y específicamente los cuarteles permitieron el funcionamiento de la policía de seguridad urbana, en términos de control social, de sanción de normas de convivencia, pero también de aspectos referidos a la vida privada y la persecución y castigo de delitos.

Esta verdadera cosmovisión del miedo que representó el Orden público, a su vez permitió a los administradores políticos de la época diagramar sobre el "tablero de damero" la noción de cuarteles, una moderna geopolítica del poder, distribuyendo poderes y saberes.

Durante el periodo colonial existían una serie de ideas y tipos de jurisdicciones territoriales, digamos, curatos, capillas, obispados, distritos, cantones, intendencias, gobernaciones, cabildos. Durante la primera mitad del siglo XIX se agregaron los cuarteles. Coherente con las jurisdicciones, actuaron obispos, curas, distintos representantes del rey con fueros "ad-hoc", intendentes, gobernadores, alcaldes y cabildantes representantes del poder colonial. Pero a partir de 1820, al tiempo que se produce una apropiación de todas estas formas de parte de los nuevos políticos, se produce una "criollización" de todas estas nociones. $Y$ emergen con mucha fuerza dos autoridades relevantes: los comisarios y subdelegados. Dos renovadas figuras representantes del poder "republicano". Estos verdaderos operadores de estrategias punitivas, distribuyeron su acción sobre el plano urbano, principalmente a través de los cuarteles.

De este modo, los cuarteles se constituyen en unas coordenadas de poder que hacen viables aspectos ideológicos vinculados a la concepción y tipo de sociedad que las elites deseaban y que preferentemente tienen que ver con determinaciones impuestas por el Orden Público.

Gracias al Orden público que le otorgó contenido ideológico al cuadriculado y los cuarteles, existieron una enorme variedad de estrategias o prácticas políticas relacionadas al control social. De una parte, se pueden observar estrategias propiamente urbanas como el cobro de impuestos, aseo urbano, funcionamiento y control institucional y de organizaciones sociales. Pero, sobre todo, los cuarteles permitieron el emplazamiento de estrategias policiales para el control de la población.

A partir de 1820 poco más o menos, los administradores políticos chilenos se ven dirigiendo progresivamente una amplia y difusa masa de población, objetivamente analfabeta y marginal. Sus principales esfuerzos se orientan precisamente a convertirlos en ciudadanos integrados, respetuosos de las leyes, trabajadores y honestos. La tarea es casi imposible o al menos difícil. Quizá por eso la "integración" normalmente se concibe por medio de mecanismos punitivos.

Más allá de lo ideológico y de las prácticas políticas, el drama de lo cotidiano se presenta tensionando al sujeto, como se verá a continuación.

\section{Práctica social: Impacto sobre la vida cotidiana}

José Zapiola, que vivió en Santiago entre 1802 y 1885, en una descripción de Santiago de la primera mitad del siglo XIX, puso en relieve la 
falta de vigilancia policial o su precariedad, ya en relación al control de actividades como los juegos o al cuidado del comercio:

Antes de 1820, no había mas guardianes de la propiedad que los guardas de las tiendas, cuyas funciones se limitaban a cuidar el reducido recinto del comercio, que no se extendia a mas de dos cuadras de la plaza, y no en todas direcciones ${ }^{45}$.

La precariedad el sistema policial republicano también quedó señalado en el escaso control de ciertos "desórdenes públicos"; en la "ausencia de serenos" o en cuanto a los objetivos policiales en $1830^{46}$. Coincidentemente, el intelectual y político José Victorino Lastarria también contemporáneo, señaló que precisamente a partir de 1830, las condiciones policiales en la ciudad de Santiago se endurecieron para la población:

El gran fin que estas autoridades han perseguido es el de abatir al pueblo, hacerlo callar, dominarlo de modo que se convenza de que no existe sino bajo la presión de la autoridad i de que nada puede hacer sin su beneplácito. Los actos diarios, los actos de cada instante de la policía no han tenido otro objeto. Los Intendentes i todos sus ajentes han hecho un dogma de la enemistad del pueblo, i no han visto en el pueblo sino a un enemigo vencido, que era necesario tener a raya, a nombre del orden i la moral pública ${ }^{47}$.

Con el objeto de mostrar la actividad policial, digamos, el modo como se desplegaban las estrategias de poder y control permitidos por los cuadrantes, recurrimos a una muestra de casos extraída de los Libros de Condena (LC). Aunque ella resulta insuficiente para sacar alguna conclusión valedera, preliminarmente permite sentar algunas situaciones dignas Santiago, 1945, p. 62.

46 Zapiola: $68,75,80,81$ y 160.

47 Lastarria 1870, 3 Vols., Vol. III: 87-97.

de comentar. La variedad de referencias al delito, lo discutible o lo complejo del análisis de la muestra, precisamente es un llamado, una invitación para levantar nuevas preguntas y una agenda de investigación con el objeto de comprender el funcionamiento del sistema policial, de vigilancia y de castigo de la sociedad de la primera mitad del siglo XIX. No obstante, a pesar de las limitantes inherentes de la muestra, el tipo de delito observado, permite graficar la capacidad del sistema policial que aprovecha el rayado urbano y sobre todo los cuadrantes para desplegar sus funciones de vigilancia y represión.

Los LC, el registro escrito de los delitos y las penas sumarias practicadas por la policía entre 1830 y 1840 , permitieron generar las siguientes categorías de delitos: sexuales, insultos, uno sin categoría, hacia la familia, ebriedad, robo, la justicia militar (que por medio del fuero se convierte en una verdadera anomalía administrativa), violencia, delitos morales y desórdenes públicos. El orden establecido en todos, si bien no implica una jerarquización en ningún sentido, en la lógica de la muestra al menos, implica un mayor número de ellos.

El "delito sexual" es muy raro encontrarlo tipificado. El único caso que aparece en el contexto de la muestra corresponde al de José Hernandez, que fue "(...) aprendido en el acto mismo de estuprar á una chica de siete años (...). El escribano dejó anotado que "...la muchacha y el padre se harán comparecer tan pronto como sea posible" (13 de julio de 1838).

Aunque para la misma época se sabe que el "trabajo doméstico" fue un delito y también castigo de las mujeres (Neira 2005: 367-390), en la muestra apenas aparece una vez. Sin embargo, ello no disminuye su importancia. Al 
respecto destaca el caso de Tránsito Moreno, quien fue "(...) condenada á un mes de corrección por el inspector Caballero por haber [se] fugado de la casa donde servia de ama dejando al chico en la necesidad" (15 de marzo de 1838). El trabajo doméstico implicó al mismo tiempo una instancia para dilinquir como el caso que se observa y un lugar de castigo. Esto es, la Moreno pudo haber llegado a esta casa, dado un delito y como resultado de un "juicio sumario".

En materia de "insultos", la muestra presentó el caso de Concepción Vasques que fue "(...) condenada por el subdelegado Puelma...á ocho días de corrección por insultos á una prima hermana suya" (20 de mayo de 1838).

El día 8 octubre de 1838, Juan Bautista Venegas y Juan Rojas, fueron arrestados “(...) el $1^{\circ}$ disfrazado con traje de mujer i casado con Maria Garcia Aguila, quien lo acusa también de que no la auxilia en nada". Este delito no ha podido ser categorizado, aunque quizá tenga que ver con delitos ocurridos en el marco familiar, tal como el que comete Marcelo Padilla, quien "(...) paso al presidio por dos meses por haberse desvergonzado con el Cura y haber intentado pegarle a su mujer" (el 27 de diciembre, 1830). Mientras que el 10 de enero, Lorenzo Pica fue detenido "(...) por incorregible, y haber cargado con su madre". A petición de ella misma, "pasó a la casa de corrección por un año, para que allí aprenda algún oficio" (1831).

La "ebriedad", corresponde a unas de las categorías que resulta más coherente con la constante preocupación de la autoridad por este mal y sus relaciones con distintos delitos. Como ejemplo, José María Pizarro, fue detenido "(...) por incorregible en el vicio de la embriaguez y ser vago", y su castigo consistió en pasar a la casa de corrección por un año" (17 de noviembre de 1831); y en 6 de abril de 1838, José Acevedo, Manuel Ramirez, Francisco Alfaro, Sebastian Garcia, Vicente Fuica, Fernando Pizarro y Tomas Silva" fueron condenados "(...) por ebrios y estar bebiendo licor en la calle pública".

La categoría de "robo", reviste tanta importancia como la anterior de embriaguez. Son los principales males de la sociedad de la primera mitad del siglo XIX. De este modo, José Antonio Montaner fue "encargado" reo por su padre, por "haberle tomado un Blandon y una tembladera de plata", por lo que fue "remitido al juez del crimen" (El 2 de julio de 1830); mientras que Pedro Olea y José Olea, fueron capturados por los vigilantes por haber "(...) rovado un poco de sevo de la casa de su patrón (...)" y por ello "pasaron al presidio por quince días" (13 de agosto de 1830). Mientras que Vicente Sanchez fue acusado "... por Pedro Cavesas de haberle robado un cavallo encillado...", por lo que "... paso al Sr. Juez del crimen" (18 de octubre de 1830). El 27 de julio de 1831, Rosario Tello fue "... convenido en distintas ocasiones de ladron ratero y últimamente tomado infraganti por la policía en el hecho de arrebatar un pañuelo a una sra. en la calle publica"; por este delito, "...paso a la casa de corrección por 10 meses"; por su parte, José Mardones fue aprehendido el 28 de septiembre de 1837 ,

\footnotetext{
“...por haber robado unas carabanas de diamantes que se encontraron vendidas en doce pesos de cuya cantidad se recogieron nueve, a la corrección por un mes sin perjuicio de pagar las carabanas".
}

Por su parte, Valerio Orellana, fue tomado preso por "...creerse complice en el salteo hecho en los molinos de doña Vicenta Curruchaga", por lo que fue derivado al juez del crimen (8 de octubre de 1838). 
Entre los casos que la policía traspasó a la "justicia militar", destacan el caso de José Agustín Riesco y Francisco Godoy, quienes "... pasaron a la corrección por tres meses (...)" y dada su condición de soldados del Batallón $\mathrm{N}^{\circ}$ 3, les correspondió ser “...desaforados por su comandante y jusgados por este por incorregibles..." (28 de septiembre de 1830). El 13 de enero de 1838, Martin Ponse pasó "(...) ocho días al presidio por ebrio"; tiempo después, Ignocencio Chavarria, soldado del escuadrón cívico $\mathrm{N}^{\circ} 2$, fue detenido "(...) por pelear en la calle con María Basuare con quien vive en trato ilícito" y en su calidad de miliciano, "pasó, al Comandante de Armas" (el 28 de febrero de 1838);

En cuanto al delito tipificado como "violencia", por su parte, el 20 de diciembre del año 1831, Cipriano Ramirez fue arrestado por “(...) haber estropeado a su mujer hasta quebrarla un braso a patadas", razón por la que "...fue destinado al juez del crimen". Y el 21 de enero de 1837, José María Sepeda (sic) fue detenido "(...) por haberle dado una gran bofetada en la cara a Juan Pizarro y haberle quebrado el hueso de la quijada", por lo que pasó al juez del crimen; mientras que José Antonio Gonzalez y Bernarda Zenteno, fueron detenidos "(...) el primero por haber forzado á una joven y la segunda por alcaueta", ambos fueron enviados al juez del crimen (28 de febrero de 1837); mientras que Santiago Campos, fue arrestado “(...) por haber maltratado á su mujer como tiene de costumbre hacerlo", por tal razón pasó al juez del crimen (7 de abril de 1837); Y en 9 de diciembre de 1837, para finalizar la muestra del año, Domingo Leon, fue arrestado "(...) por haber muerto ahora tres años a Francisco Llanos y le acuso la viuda", por tal razón fue remitido al juez del Crimen.

Bajo la categoría de "delitos morales", destacan el caso de Carmen Alvarez, que fue detenida, "(...) por estar viviendo en mala amistad con Nicolas Cofre paso a la casa de corrección por dos meses" (23 de noviembre de 1830); es interesante igualmente, el caso de Matías Muñoz, quien fue arrestado por "(...) estar viviendo amancebado", por lo que fue enviado "al presidio por un mes" (21 de marzo de 1831); igualmente destaca el arresto y castigo a Getrudes Lopez, “....por estar en una vida escandalosa en la jurisdicción de Renca y haber causado la desunión de un matrimonio virtuoso", por lo que fue castigada con cuatro meses en la correccional (19 agosto de 1831). A lo anterior se suma el caso de José Maria Castro y Juana Quiroz, quienes fueron "(...) conducidos a este Quartel y remitidos al juzgado del crimen por haber sido acusados por la Maria Salazar mujer de Castro de estar estos viviendo en ilicita amistad" (26 de septiembre de 1831); mientras que Mercedes Garrido "(...) fue aprendida a pedimento de su marido por haber acreditado ante el inspector Yavar ser una mujer insufrible en maldades (...)", por lo que fue sancionada "pasando a la corrección por dos meses" (3 de octubre de 1831); mientras que Mercedes canales, fue "(...) remitida por el Prefecto Don Jose Donoso Pizarro por amancebamiento con un hombre casado", lo que le hizo merecedora de un encierro en la corrección por cuatro meses (19 de junio de 1837); Lorenzo Frez, por su parte, fue "(...) acusado por doña Pabla Garcia de haber seducido una joven de 14 años" y remitido "por el inspector Valdes al juez del crimen" (21 de agosto de 1837); mientras que Rafaela Rodriguez fue "(...) condenada en apelación por el subdelegado Silva, á dos meses de corrección por trato ilícito con el marido de María Rios" (30 de junio de 1838); José Alvarez fue aprendido "(...) por los serenos a solicitud de su mujer Dolores Palomera, quien encontró a aquel en el cuarto de Rosario Aviles, con la cual vive en ilisita amistad" (10 de septiembre de 1838); también 
destaca el caso de Cecilia Salazar, que fue "(...) condenada por el Subdelegado Puelma a seis meses en la corrección a solicitud de su marido Severo Arebalo por haberse fugado de su casa en distintas ocasiones y andar con unos y otros" (13 agosto de 1838).

El delito de "desórdenes públicos", surge de la causa de Pedro Ignacio Guajardo que "(...) pasó al presidio por seis meses por haber armado desordenes en la calle publica y haber cargado con los vigilantes" (27 de febrero de 1831). Mientas que el caso de Norberto Gonzalez, destaca porque fue aprendido "(...) por ebrio y haber querido pelear con el vigilante", razón por la cual "pasó al presidio por quince días" (10 de abril de 1831); o el de José Lira que "(...) por haber corrido con cuchillo unas mujeres y haver insultado a los vigilantes", pasó directamente "la presidio por un mes" (16 de mayo); o el caso de Jose Maria Machuca que el 21 de junio de 1831 fue "(...) pillado infraganti rovando en la casa de don Luis Gomes en donde había vaciado unos vaules llevándose varias especies y quatro pesetas en plata, que a poco andar con el rovo fue tomado con el y se entrego a dicho Sr., pasó al juez del crimen". Destaca igualmente el caso de Pedro Lujan que "(...) por ebrio consuetudinario, vago y andar buscando pendencia en la calle publica", su arresto lo hizo acreedor de una pena de seis meses en el presidio (2 de marzo de 1837). Mientras que Manuel Mejías, se sumó a los arrestos policiales, por "(...) haber herido y desarmado en compañia de otros a un vigilante, en cuyo atentado es reincidente" (18 de mayo de 1837). Mientras que Patricio Espinoza y Bernardo Contreras, por su parte, fueron "(...) remitidos por el subdelegado de Ñuñoa por haber herido con cuchillo a Felipe Mardones y Rufino San Juan", por tal razón fueron despachados al juez del crimen (27 de julio de 1837). El 13 de octubre de 1837, Agustín Muños (sic), fue detenido "(...) por haber herido con cuchillo a Juan Malverde, al presidio seis meses"; y José Tapia, fue detenido "(...) por haber usado de palo con su mujer Josefa Tapia, (...) estará en los trabajos interiores del presidio seis meses (...)" (19 de noviembre de 1837).

De la muestra, llama la atención el hecho que estos casos corresponden a conductas que a nuestros ojos no comportan delito, ni a las personas ni a la propiedad. A excepción del delito sexual, cuando más, pudieron ser simples transgresiones a ciertos preceptos familiares o incluso básicamente citadinos. Dicho de distinta manera, del total de las manifestaciones delictivas aparecidas en la muestra, ninguna es de consideración, digamos, ninguna es estratégica. Ninguna pone en cuestión el funcionamiento de la sociedad, ni en sus partes ni en el todo, ni menos tienen relación con los "miedos" que pudieran mostrar la elite. Del mismo modo, no responden a vestigios de crimen organizado, ni calculado o planificado. Menos, a "turbas urbanas" como la idea que tiene de Hobsbawm (1983: 165 a 190). Subsecuentemente, no tienen que ver con los movimientos prepolíticos que rastrea Grez (1997: 31). Precisamente, esta ausencia hace que José Luis Romero exprese en la propia Presentación al libro de Grez ya citado, que éste “...no le asigna importancia central a las formas 'premodernas' de la organización y la acción (p. 20).

Aunque, por otro lado, no se puede negar la existencia y actividad de cofradías, sociedades, protopartidos políticos, amparados en una necesaria mirada institucional o corporativa de la sociedad del momento, tal como no se puede 
desconocer el descontento y la existencia de revueltas espontáneas (Grez 1997).

El presente trabajo en cambio, exploró el nivel de vida cotidiana, resultado eso sí, de aspectos ideológicos y la práctica política. Entonces, si nos apuran, se encuentra más cercana a la infrapolítica de Scott (2000). El delito, entonces, contendría rasgos de contracultura, dado su carácter marginal, constituyéndose en una infrapolítica pública.

En cualquier caso, gracias a la denuncia o a la calidad de "sorprendido infraganti", la policía pudo arrestar a "delincuentes" irrelevantes, que fueron detenidos y encerrados directamente o fueron remitidos al juez del crimen y algunos todavía, aquellos que tenían "fuero", que eran milicianos, eran derivados al Comandante general de Armas, a la justicia militar.

En todos los casos, los arrestos son resultado de una actividad de vigilancia, disuasión y represión de un sistema policial cuya eficiencia y efectividad se debió al despliegue espacial determinado por las cuadras, pero muy especialmente en función de los cuadrantes o cuarteles.

Estas prácticas de los grupos subalternos, son transgresiones irrelevantes. Pese a ello, sin embargo, justifican la desconfianza que la elite siente hacia las masas.

\section{Conclusiones}

El estudio comprueba con la hipótesis. La ciudad de Santiago de la primera mitad del siglo XIX efectivamente fue opresiva a partir del trazado de damero.
La particularidad de nuestro enfoque, sostenido en una historia social crítica, hizo posible entregar algunos elementos para la comprensión de nuestro objeto de estudio.

Esto es, el poder y sus estrategias encontraron en el plano de damero el más relevante aliado, llegando a ser un verdadero soporte físico para que el Orden público, un componente ideológico, digamos, abstracto, se objetivara en unas prácticas políticas que finalmente justificaron la implementación de unas prácticas sociales en procura del control de la población. Dicho de otra manera, sobre el plano de damero, entonces, se instaló la compleja noción de los cuadrantes que permitió a la policía vigilar, conocer y controlar represivamente un territorio urbano específico, teniendo como referente, además, la noción de "orden público".

La existencia de la noción de cuadrantes demuestra que la élite actuó con un grado de pensamiento racional sorprendente para la época. $Y$ hace suponer que mientras el crecimiento urbano no significó un problema, es probable que este sistema haya reportado enormes beneficios a la autoridad. Pero ies posible articular un proceso secular de las coordenadas de poder? $Y$ entonces, ¿por qué esta estrategia de poder se "invisibiliza" durante la segunda mitad del siglo XIX y la primera mitad del $X X$ y reaparece como un notable invento de fines del siglo XX y comienzos del XXI? Estas son preguntas de una agenda investigativa de "Iongue dureé", principalmente en una dimensión ideológica y social del fenómeno; mientras que la dimensión política del mismo, quizá esté más marcada por los énfasis de las coyunturas.

En cualquier caso, el sistema policial desplegado sobre estas coordenadas de poder durante la 
primera mitad del siglo XIX, dan cuenta de un tipo de delito muy singular. Un fenómeno distinto de conductas sociales como las luchas políticas o revueltas de alguna envergadura, las que quizá, el poder las pudo resolver utilizando otros mecanismos distintos al policial. La variedad de fuentes utilizadas, no son concluyentes.

Pero los tipos de delitos y transgresiones, que emergen de la lógica de cuadrantes y del sistema policial, eso sí, "operan" a nivel de vida cotidiana y de un sujeto que es fronterizo, puesto que, aun cuando vive integrado a la sociedad, intermitentemente elige ser transgresor de las normas de convivencia más elementales. Esta inconsistencia entre la vida integrada y la automarginalidad, hacen sospechar de un fenómeno elemental de resistencia.
Y sin embargo, la muestra de delitos y condenas, desde 1830 a 1840, permite dejar una primera evidencia y es que estas transgresiones no llegan a constituirse en estrategias de resistencia propiamente. La masa no posee un programa, ni discurso. Tampoco se observa algún tipo de organización. Mucho menos aparece de manera declarada ni subyacente el principio de coste-beneficio de raigambre utilitarista "Benthamiano" en la que abría insistido Foucault (1998). Más interesante podría resultar una especie de "anomia" que parece dominar todas estas prácticas transgresoras. El delito que se observa, con las limitantes de la muestra, parece que se mueve más que nada por el principio de la oportunidad. Por eso mismo son delitos irrelevantes.

\section{Bibliografía}

Aguila, E. y Maldonado, C. 1996. "Orden público en el Chile del siglo XX: trayectoria de una policía militarizada". Justicia en la Calle. Ensayos sobre policía en América Latina, Waldmann, P. (ed.) Colombia: Biblioteca Jurídica. 73 - 98.

Bascuñan, A., y de Avila, A. 1941. Notas para el estudio de la criminalidad y la Penalogía en Chile (1673-1816). Santiago: Universidad de Chile, Seminario de Derecho Público, Escuela de Ciencias Jurídicas y Sociales de Santiago, Imprenta el Esfuerzo.

Braudel, F. 1984. Civilización Material, economía y capitalismo, Siglos XV-XVIII. Madrid: Alianza editorial, 3 vols., Vol. III. El tiempo del mundo.

Caviéres, E. 1993. La Serena en el S. XVIII. Las dimensiones del poder local en una sociedad regional. Valparaíso: Ediciones Universitarias, Universidad Católica de Valparaíso.

Cobos, M. 1980. "El Juez de Campo". Revista de Estudios histórico-jurídicos V: 85-166.

Collier, S. 1989. "Gobierno y sociedad en Chile durante la 'República Conservadora', 1830-1865". Boletín del Instituto de Historia y América "Dr. E. Revignani”, 1, tercera Serie: 115-126. . 1985. Chile. Bethel, L. (ed) Historia de América Latina, Cambridge, University Press, Editorial Crítica, Barcelona, 1985, Vol. 6, América Latina Independiente. 1820-1870. 1982. "Conservantismo chileno, 1830-1860. Temas e imágenes”. Nueva Historia. Londres: 2 (7): 143-163.
Durston, A. 1994. "Un régimen urbanístico en la América hispana colonial: El trazado en damero durante los siglos XVI y XVII". Historia 28: 59-115.

De Ramón, A. 2000. Santiago de Chile (1541-1991). Historia de una sociedad urbana. Santiago: Editorial Sudamericana.

y Larraín, J. 1982. Orígenes de la vida económica chilena (1659-1808). Santiago: Centro de Estudios Públicos.

Escala, M. 1980. Síntesis esquemática de la policía uniformada chilena en sus diferentes etapas, Colección Documentos para la Historia de Carabineros de Chile. Santiago.

1978. "La policía durante el gobierno de O'Higgins". Revista Chilena de Historia y Geografía 146: 251-267.

1975. Proceso evolutivo de las fuerzas policiales uniformadas chilenas. 1541-1974. Santiago: Talleres de Revista AQUÍ ESTA.

Foucault, M. 1998. Vigilar y castigar. El nacimiento de la prisión. México: Editorial Siglo Veintiuno.

Galdames, L. 1903. La lucha contra el crimen. Santiago: Imprenta de Enrique Blanchard-Chessi.

Gay, C. 1854. Atlas de la Historia Física y política de Chile. París: Imprenta de E. Thunot y Cia.

Guarda, G. 1965. "Santo Tomás de Aquino y las fuentes del urbanismo indiano". Boletín de la Academia chilena de la Historia, 72, Santiago: 5-105. 
Góngora, M. 1998. Ensayo histórico sobre la noción de Estado en Chile en los siglos XIX y XX. Santiago: Editorial Universitaria.

Grez, S. 1997. De la "Regeneración del Pueblo" a la huelga general. 1810-1890. Santiago: Centro de investigaciones Diego Barros Arana.

Hernández, R. y Salazar, J. 1994. De la policía secreta a la policía científica. Proceso histórico policía de investigaciones de Chile, Santiago, 3 vols., Vol. I.

Hobsbawm, E. 1983. Rebeldes primitivos. Estudio sobre las formas arcaicas de los movimientos sociales en los siglos XIX y XX. Barcelona, Editorial Ariel.

Iglesias, S. 2010. "La Evolución del concepto de orden público a través de las constituciones españolas hasta 1812". Revista de Derecho UNED 7: 373-402.

Jimenez, G. 1986. Historia de la policía uniformada en Chile. Desde 1541 al 1986. Santiago: Ediciones Históricas de Chile Ltda.

Kagan, R. 1997. "Un mundo sin murallas, la ciudad en la América Hispánica colonial”, Imágenes de la diversidad. El mundo urbano en la corona de Castilla (S. XVI-XVIII). Fortea, J. (Ed.). España: Universidad de Cantabria. 51-86.

Le Goff, J. 1992. La civilización del occidente medieval. Buenos Aires: Ediciones Paidós.

1982. Mercaderes y Banqueros de la Edad Media.

Buenos Aires: Editorial Universitaria.

Lezama, J. 2008. Teoría social, espacio y ciudad. México: El Colegio de México.

Lösing, N. 1996. "Realidad y perspectivas de la policía en América Latina. Resumen y reflexión", Justicia en la Calle. Ensayos sobre policía en América Latina. Waldmann, P. (Ed.). Colombia: Biblioteca Jurídica. 381-404.

Miranda, D. 1997. Un siglo de Evolución policial de Portales a Ibañez. Santiago: Departamento de estudios históricos, Instituto Superior de Ciencias Policiales, Carabineros de Chile.

Morse, R. 2003. "El desarrollo urbano de la Hispanoamérica colonial", Historia de América Latina. Bethell, L, (Ed.). Barcelona: Editorial crítica, Varios vols., Vol., 3, América Latina colonial: economía. 15-48.

1962. "Some characteristic of the Latin American

Urban History", in American Historical Review, 67: 317-338.

Monclus, F. y Oyon, J.L. 1982. Espacio urbano y sociedad: algunas cuestiones de método en la actual historia urbana. Urbanismo e historia urbana en el mundo hispano. Madrid: Editorial A. Bonet Correa. v. I.

Neira, M. 2014. "La delación como mecanismo de poder: aproximación al problema en la historia de Chile, primera mitad del siglo XIX". Revista Espacio Regional 1 (11): 39-56.

y Aguilef, P. 2011. "Para la historia del sistema policial en Chile: reglamento de policía de Valdivia de 1829". Revista Espacio Regional 2 (8): 133-146.

2005. "Castigo femenino en Chile durante la primera mitad del siglo XIX". Historia 37 (2): 367-390.

2004. "Jeremy Bentham y el liberalismo en Chile durante la primera mitad del siglo XIX". Boletín de la Academia Chilena de la Historia, 113: 285-313.

2002. "Delito femenino en Santiago de Chile. Primera mitad del siglo XIX". Revista Mapocho 51: 119-338.

Ovalle, A. 1646. Histórica relación del Reyno de Chile. Roma: Francisco Caualo. Roma.

Peri, R. 1982. Apuntes y transcripciones para una historia de la función policial en Chile. Santiago: Imprenta Carabineros de Chile. IV Vols., Vols. 1 y 2.

Pirenne, H. 1939. Historia Económica y social de la Edad Media. México: Editorial Fondo de Cultura Económica.

Rojas, M. 2011. "La ciudad como agente moralizador: la policía y la ciudad de Concepción (Chile), 1850-1880". Historia 44 (2): 443-465.

Romero, J. L. 1990. "Los sectores populares urbanos como sujetos históricos". Santiago. Proposiciones (19): 268-278.

Rosales, G. 2000. Perfiles Institucionales. Doctrina bajo el lema 'orden y patria'. Santiago: Imprenta Antártica Quebecor S.A.

Sáenz, I. 2015. "El Damero en discusión". Terra Brasilis (Nova Série) [Online], 4, posto online no dia 12 Fevereiro 2015, consultado o 03 Novembro 2015, 4, URL: http://terrabrasilis. revues.org/1129 DOI: terrabrasilis.112910.4000/.

Salazar, G. 2009. Mercaderes, empresarios y capitalistas. Santiago: Editorial Sudamericana.

Scott, J. 2000. Los dominados y el arte de la resistencia. Discursos ocultos, México D.F.: Ediciones Era.

Silva, R. 1954. Ideas y confesiones de Portales. Santiago: Editorial del Pacifico.

Stuardo, C. y Eyzaguirre, J. 1952. Contribuyentes, autoridades, funcionarios, agentes diplomáticos y consulares. Santiago: Editorial Universitaria

Stuardo, C. 1959. "Vecinos de Santiago en 1808". Boletín de la Academia Chilena de la Historia, 60, Primer semestre de 1959: 205-220.

Tobar, H. 1951. La policía preventiva o de seguridad. Orígenes, evolución y fundamentos jurídicos. Valparaíso: Imprenta Ahorronac.

Urzúa, W. 1939. Las instituciones policiales de Chile. Reseña histórica escrita en cumplimiento a una comisión de la Dirección General de Carabineros de Chile. Santiago: Dirección General de Carabineros de Chile.

Valdés Vijil, M. 1870. Recopilación de las Leyes, Ordenanzas, Reglamentos $i$ demás disposiciones de policía vijentes en el Departamento de Santiago (Rec. Realizada por Osvaldo Rengifo y Alberto C. Patiño). Santiago: Imprenta de "El Independiente".

Vicuña Mackenna, B. 1869. Historia crítica y social de la ciudad de Santiago desde su fundación hasta nuestros días (1541 - 1858). Valparaíso: Imprenta del Mercurio. Valparaíso. Varios Vols.

Waldmann, P. 1996. Justicia en la Calle. Ensayos sobre policía en América Latina, Colombia: Biblioteca Jurídica.

Zapiola, J. 1945. Recuerdos de treinta años. Santiago: Editorial Zig-Zag. 